International Journal of Instruction e-ISSN: 1308-1470 • www.e-iji.net

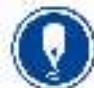
July $2021 \bullet$ Vol.14, No.3
p-ISSN: 1694-609X
pp. 359-374

Article submission code:

20200427081351

Received: $27 / 04 / 2020$

Revision: 20/12/2020

Accepted: 13/01/2021

OnlineFirst: 22/05/2021

\title{
The PINTER Learning Model to Enhance Higher Order Thinking and Communication skill in Algebra
}

\section{Heru Kurniawan}

Doctoral student of Teacher Training and Education Faculty, Sebelas Maret University \& Mathematics Department, Muhammadiyah University of Purworejo, Indonesia, herukurniawan@student.unc.ac.id \& herukurniawan@umpwr.ac.id

\section{Budiyono}

Prof., Teacher Training and Education Faculty, Sebelas Maret University, Solo, Indonesia, budiyono@staff.uns.ac.id

\section{Sajidan}

Prof., Teacher Training and Education Faculty, Sebelas Maret University, Solo, Indonesia, adjid@fkip.uns.ac.id

\section{Siswandari}

Prof., Teacher Training and Education Faculty, Sebelas Maret University, Solo, Indonesia, siswandari@staff.uns.ac.id

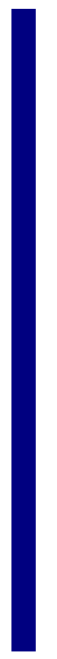

The issue of higher-order thinking skills in Indonesia began to be raised in line with the changing goals of mathematics learning. The efforts have been made to be able to produce improved thinking skills, one of which is the PINTER model. This study aimed to see if there are any differences in higher-order thinking skills and mathematical communication between students who learn using the PINTER mathematics learning model and students who learn using conventional learning models. This research was a quasi-experimental study with all 7th-grade students of SMP in Purworejo Regency as a population. Stratified cluster random sampling was used to draw a sample of 91 students for the experimental group and 96 students for the control group. The research instrument utilized multiple-choice tests and essays given at the end of the 5th learning meeting. A multivariate F-test followed by a univariate t-test was used to analyze data. The results of the study show that: 1) students 'higher-order thinking skills that are subjected to learning PINTER mathematics are better than students who are subjected to traditional learning models, and 2) students' mathematical communication skills that are subjected to learning PINTER mathematics are better than students who are subjected to traditional learning models.

Keywords: the PINTER mathematics learning model, hots, mathematics communication skills, algebra

Citation: Kurniawan, H., Budiyono., Sajidan., \& Siswandari. (2021). The PINTER Learning Model to Enhance Higher Order Thinking and Communication skill in Algebra. International Journal of Instruction, 14(3), 359-374. https://doi.org/10.29333/iji.2021.14321a 


\section{INTRODUCTION}

The implementation of the 2013 curriculum by the National Education Ministry of the Republic of Indonesia is a response to the TIMSS study report in 2011 and PISA in 2012. The implementation of the 2013 education curriculum is expected to have a significant impact on improving the quality of education in Indonesia. However, this does not seem to be enough, the 2015 TIMSS results ranked Indonesia 44th out of 49 participating countries and the 2015 PISA results ranked Indonesia 62nd out of 70 participating countries. The results of the TIMSS and PISA studies provide a real picture that only a small proportion of Indonesian students can demonstrate advanced thinking skills.

The PISA 2015 results show that the average mathematics score with a score of 386. Based on the average score, Indonesia falls into the Level 1 category which is characterized by students who can complete assignments with low problem complexity and complexity with limited collaboration. They can provide the information requested and take action to make plans when requested. Students can confirm actions or proposals made by others. They are usually preoccupied with their positions in the student community. With the support of team members, and when working on simple problems, these students can help find solutions to the problems given.

In terms of curriculum elements, one of the aims of learning is to develop problemsolving skills (Sari, Sumarmi, Utomo, \& Astina, 2021). The PISA results imply that Indonesian students still find it difficult to solve mathematics problems with a high degree of complexity. This happens because students are accustomed to dealing with problems with a low level of difficulty and do not require advanced thinking processes. This is reinforced by the finding of the investigation result of students' mathematical skills in which nearly $30 \%$ of Indonesian students showed medium performance and less than $5 \%$ showed high performance. The rest shows low performance.

The low ability of students in advanced thinking and less optimal student activity in group work as in the PISA report above encourages the need for improvement in the quality of learning. This is what underlies this research. Increasing higher-order thinking skills and mathematical communication is one thing that must be improved and must be an integral part of learning mathematics in the classroom. Achievement of higher-order thinking skills and mathematical communication. HOTS (Higher-Order Thinking Skills) has a very important impact on student involvement with mathematics and improving student performance in various fields (Tajudin, 2017). Communication skills are important to be mastered by students because they are related to the development of one's creativity. Decision-making is what enables you to turn a jumble of ideas into coherent communication (Intratot, 2016). Based on this, the research is very necessary to do because it will have a positive impact on the lives of students in the future. Students who have good HOTS abilities are believed to be more successful than those who only have LOTS of abilities (Yuniarti \& Fitri, 2019).

HOTS must be the main goal and focus in education (Absolem, 2016) and be one of the keys to increasing student learning achievement (Thompso, 2008). The teachers have agreed that teaching HOTS to students is something that must be emphasized to guide 
and encourage the emergence of student ideas. The empowerment of higher-order thinking skills and mathematical communication are very compatible with socioeconomic developments, information technology development, and other global challenges. HOTS also influences student achievement. The findings also indicate that high-level thinking skills are linked to student achievement positively and importantly (Sutrisno \& Retnawati, 2018).

Mathematical abilities tested in the 2019 National Examination include numbers, algebra, geometry, and statistics. Of the four materials, the percentage of students who responded correctly were Numbers (39.71\%), Algebra (51.24\%), Geometry (42.27\%), and Statistics $(55.60 \%)$. From the above results, researchers see that algebra requires more attention. Algebra can be seen as a gateway for mathematics as a whole. The concept of algebra (variables, coefficients, constants, etc.) is almost certainly used in other materials. Algebra can be used as a gateway to improve high-order thinking skills for all mathematical material. Many contextual problems can be presented in the form of algebra so that they can be used as a training tool to develop mathematical thinking skills.

Algebra is a mathematical discipline that deals with variables, coefficients, constants, symbols, and operations, among other things. However, mastering algebra requires more than just memorizing symbols; it also entails being able to apply algebraic knowledge in real life. Teachers should emphasize that algebra is necessary for any success in mathematics, and abstract algebra is needed for advanced mathematics and the life and work opportunities that come with higher education in a variety of fields (Kartz, 2007). On the other hand, in today's ever-changing digital age, progress in algebra and courses beyond algebra is essential (Hill, 2010). It was also mentioned that algebra is a key to higher achievement, implying that mastering algebraic concepts contributes to the development of more advanced mathematical skills (National Mathematics Advisory Panel, 2008). When students' misconceptions and errors are considered, they may trigger bigger problems in future algebra topics (Sahin and Soylu, 2011). A misconception that occurs in students is significantly affected by the learning implemented by the teacher. Concept mistakes can be fatal because they will not lead students to the expected completion. Especially if it is associated with higher-order thinking problems, such students will surely experience difficulties.

The main key to achieving success in learning is through the application of an appropriate learning model. It cannot be denied anymore, that the teacher plays a very crucial role in the success of students (Mantiri, 2015). This can be interpreted that efforts to achieve higher-order thinking skills and mathematical communication are very dependent on the learning process carried out by the teacher. Learning to improve highorder mathematical thinking skills has been done by researchers and experts before. Some of them suggested that learning should include the following steps: 1) establish learning goals, 2) teach by questioning, 3) practice prior to the examination, 4) evaluate, refine, and develop, and 5) provide guidance and assessment of learning (Limbach and Waugh, 2006). Another opinion states that the increase in HOTs can be done through 1) activating the student's prior knowledge, 2) using classroom activities, 3) grouping approach and 4) assessment forms (Saido, Siraj, and Nordin, 2015). Mathematics 
classroom must do the following things to achieve an effective environment for higherorder thinking: 1) Actively engage in doing mathematics, 2) Solve challenging problems, 3) Make interdisciplinary connections, 4) Share mathematical ideas, 5) Use multiple representations to communicating mathematical ideas, and 5) Use manipulatives and other tools (Protheroe, 2007).

Strategies identified by the participant teachers to enhance mathematical communication are (a) giving real-life examples, (b) question-answer techniques, (c) peer learning techniques, (d) activities and games (Rich and Aydin, 2014). Mathematical communication can also be improved through small group discussions and class discussions (Cooke and Buchholz, 2005). Besides that, it can also be improved by giving open-ended questions (Stein, Smith, Henningsen \& Silver, 2000).

In contrast to the research and learning steps above, in this study, the improvement of higher-order thinking skills and students' mathematical communication will be improved by using the PINTER learning model. This learning model is a synthesis of several learning steps that have been mentioned above as a result expected to provide improvements in the quality of mathematics learning especially algebra material. PINTER is an acronym for the syntax used: 1) Presentation to real life, 2) Investigation, 3) Team Activities, 4) Elaboration, and 5) Reinforcement.

\section{Research Problem}

Based on the background of the problem above, the research problem of this study is: 1) Are higher-order thinking skills in students taught with the PINTER math learning model better than higher-order thinking skills in students taught with traditional learning models? and 2) Are mathematical communication skills in students taught with the PINTER math learning model better than mathematical communication skills in students taught with traditional learning models?

\section{Literature Review}

\section{Higher Order Thinking Skills}

The literature on thinking skills leads to 2 (two) different understandings, namely: thinking low level (Low Order Thinking/ LOT) and thinking high level (High Order Thinking/ HOT). Based on the revised Bloom taxonomy it is stated that the top three domains which include analyzing, evaluating, and creating are categorized as Higher Order Thinking Skills (Zoller, 1993; Anderson and Krathwohl, 2001; Pecka, 2014; Heng and Ziguang, 2015). Higher-order Thinking is an 'umbrella term, including concepts such as creative, systemic, and critical thinking, encompassing various forms of thinking such as critical, systemic, and creative thinking (Resnick, 1987). To have high-order thinking skills must be accustomed to using a variety of mathematical thinking skills, such as reasoning, analyzing, evaluating, creating, organizing, systematic thinking, complex thinking, critical thinking, and creative thinking.

In another understanding from some experts, it is stated that HOTs is a student's skill to interpret or represent mathematical problems through various mathematical thinking skills to be able to produce non-procedural solutions. Mathematical problems in this definition are interpreted as non-routine problems that are challenging and involve 
several other material concepts (Resnick, 1987; King et al, 1998; NCTM, 2000; Lopez and Whittington, 2001; Thompson, T, 2008; Thomas and Thorne, 2010; Heong, et al, 2011; Guest, 2011; Center for Development and Learning, 2013; Goethals, 2013; Kruger, 2013).

Mathematical thinking skills include the ability to think logically, systematically, analyze, evaluate, create, reason, think critically, and think creatively. The nonprocedural settlement is meant to be an uncertain solution, not easy to guess, or not as exemplified earlier. Based on the description, the students are stated to have high-level thinking skills if 1) able to use a variety of mathematical thinking skills, 2) able to present problem-solving that is not procedural.

\section{Mathematic Communication Skills}

Communication is generally understood as an activity to convey messages to others. Communication is seen as an attempt to make other people act or feel according to one's intentions (Nilsson and Ryve, 2010). The success of the communication process is when the message conveyed by the message maker can be well received and understood by the recipient of the message. In the scope of effective mathematical communication learning is a respectful but engaged conversation in which students can clarify their thinking and learn from others through talk (Chapin, O'Connor, and Anderson; 2003).

Communication generally takes place in two ways, oral communication, and written communication. Both writing and discussion are seen as integral parts of communication that promote a deeper understanding of concepts (Cramer \& Karnowski, 1995; NCTM, 2000). If a student did not participate in the discussion group, this would have an impact on the group's final score. During the implementation, some students in one group were found to be inactive, but students from other classes did not abandon them and instead assisted them in solving the problems (In'am \& Sutrisno, 2021). Therefore, developing communication through group discussion activities is very important. This study is more intended for written communication. Writing will not only clarify students' thinking but also provide other students with fresh insights gained from viewing the problem explanation from a new perspective (Lomibao, Luna, and Namoco; 2016). Writing has received so much attention in the mathematics classroom is because writing develops students' mathematical content learning and problem-solving skills (Bagley \& Gallenberger, 1992; Meel, 1999).

Based on the above understanding, written communication skills can be understood as skills to manage and use writing, pictures, graphs, tables, diagrams, notations, symbols, and other mathematical languages in writing to clarify, test, explaining mathematical ideas and knowledge possessed by each student to others so that others (teachers and other students) can understand and have new perspectives for problem-solving activities.

\section{The PINTER Mathematics Learning Model}

The PINTER learning model was created using the above-mentioned learning steps as a foundation. While this learning model was created primarily for algebra content, it has the potential to be extended to other subjects. 
The PINTER mathematics learning model was developed through a synthesis of cognitive learning theories and the research results presented above. The learning syntax of the PINTER model has been specifically designed for the achievement of higherorder thinking skills and mathematical communication. Special characteristics that distinguish it from other learning models are the necessity of using contextual teaching aids, the use of non-routine problems in the form of worksheets, and the existence of small group activities or class discussions to accommodate students' communication skills. The use of non-routine problems is very necessary so that all potential mathematical thinking skills of students can be optimized to produce various alternative problem-solving procedures.

Table 1

Syntax and learning strategies of the PINTER model

\begin{tabular}{|c|c|c|}
\hline No & Syntax & Strategies \\
\hline 1 & $\begin{array}{l}\text { Presentation to } \\
\text { real life }\end{array}$ & $\begin{array}{l}\text { a. Presenting contextual problems } \\
\text { b. Using learning media related to the material } \\
\text { c. Allow students the opportunity to solve a given problem }\end{array}$ \\
\hline 2 & Investigation & $\begin{array}{l}\text { a. Improve understanding of concepts through learning activities } \\
\text { with the Concrete-Pictorial-abstract approach } \\
\text { b. Resolving problems with the Bar model }\end{array}$ \\
\hline 3 & Team Activities & $\begin{array}{l}\text { a. Provide non-routine problems } \\
\text { b. Internal group discussion } \\
\text { c. Give open-ended student worksheet }\end{array}$ \\
\hline 4 & Elaboration & $\begin{array}{l}\text { a. Present the results of group work } \\
\text { b. Discussion between students in } 1 \text { class }\end{array}$ \\
\hline 5 & Reinforcement & $\begin{array}{l}\text { a. Giving individual problems } \\
\text { b. Review, refine, and feedback } \\
\text { c. Conclude learning activities }\end{array}$ \\
\hline
\end{tabular}

The PINTER math learning model is a mathematical learning model designed to enhance students' cognitive constructs to promote better learning experiences through the development of contextual, fun, relaxed, motivating, and friendly learning environments, and also the use of non-routine problems to improve high-level thinking skills. PINTER's mathematics learning model prospers because it stresses the development of students' cognitive systems to produce effective learning. Three cognitive processes, namely generalizing, synthesizing, and abstracting, are required for a mental representation of given knowledge (Naveneedhan, 2007).

Generalizing is accomplished in the PINTER mathematics learning models by relating material principles through the use of concrete objects. Synthesizing is accomplished by using pictorial types to introduce the idea of algebraic operations (addition, subtraction, multiplication, and division). Consider the following situation: "Mother purchased four mango baskets and six mangoes. Her neighbor then gave her two mango baskets and three mangoes. What is the current number of mangoes in her possession?" As a result, previously mastered concepts of variables and constants are related and acted upon by comprehending more complex concepts. The process of abstracting is accomplished by 
posing problems as word problems. At this stage, students can apply all of the previously learned information and skills to solve non-routine problems.

By communication exercises and the habit of posing non-routine problems, it is hoped that students' cognitive structures will be shaped and improved throughout the learning process. Due to the sharing of a lot of information and expertise, discussions between students in team activities and discussions between students will improve the cognitive structure of students. Students will be guided to use logical comprehension, reasoning, and multiple problem-solving techniques by non-routine problem-solving. Higher-order thinking skills will be developed as a result, especially in the algebra material.

\section{METHOD}

\section{Research Method}

This study uses a randomized static group comparison design in quasi-experimental research. The research was carried out between September and October 2019. The research population was all 7th-grade junior high school students in Purworejo Regency. Two groups are compared, namely groups that are subjected to the PINTER Mathematics Learning Models (experimental group) and groups that are subjected to traditional learning models (control groups). Both groups are in the same condition, both in terms of academic achievement, the teacher who teaches, and the textbook used. Teachers who teach have been declared as professional teachers who are shown by having a certificate as a professional educator. The textbooks used are also the same, namely using Electronic School Books published by the Indonesian Ministry of National Education.

\section{Population, Sample, and Sampling Techniques}

The participants in this study were all 7th-grade students at Purworejo Regency Junior High School (SMP) with an average age of 13 - 15 years old. The number of SMP in Purworejo Regency is 43 schools. Stratified cluster random sampling was used as the sampling method. Based on previous National Examination results, all schools are divided into three levels: high, medium, and low achievers. In each category taken one school by drawing. SMP N 5, SMP N 12, and SMP N 13 were obtained as an experimental group, while SMP N 3, SMP N 16, and SMP N 14 were obtained as a control group. The experimental group consisted of 91 students, 42 of whom were male students and 49 of whom were female students. A total of 96 students were in the control group, with 47 male students and 49 female students.

Table 2

Description of the research sample

\begin{tabular}{lllllll} 
& \multicolumn{1}{l}{ Experimental Group } & \multicolumn{4}{l}{ Control Group } \\
\cline { 2 - 8 } & SMP 5 & SMP 12 & SMP 13 & SMP 3 & SMP 16 & SMP 14 \\
\hline Male & 14 & 16 & 12 & 15 & 18 & 14 \\
\hline Female & 17 & 14 & 18 & 17 & 14 & 18 \\
\hline Total & 31 & 30 & 30 & 32 & 32 & 32 \\
\hline
\end{tabular}




\section{Research Instruments}

The data collection tool was a collection of assessments that assessed problem-solving abilities. The test lasts 80 minutes and includes 20 multiple-choice questions and 5 test essay questions. The multiple-choice test is used to measure students' HOTs, while the essay test is used to measure higher-order thinking skills and mathematical communication skills at the same time.

The content validity of the test instrument was assessed through the evaluation of three experts (expert judgment) to ascertain their approval of the test. Furthermore, the results of the assessment among 3 experts were calculated to produce an understanding between the experts of the test instrument. The calculation results from the three experts obtained an average of 3.6 (maximum score of 4.0). The reliability of the multiple-choice test was $\mathrm{r} 11=0.874$ with KR-21, and the essay test was $\mathrm{r} 11=0.936$ with Alpha Cronbach. Both groups take tests at the end of the fifth learning session.

\section{Data Collecting}

The data collected in this study are in the form of data on student work after completing the tests given. In the multiple-choice test, the test score is determined by giving a score of 1 for each correct answer and a score of 0 for each wrong answer. In the description test to assess higher-order thinking skills, an analytic assessment rubric is used with a maximum score of 8 for each question. The holistic assessment rubric is also used to see the quality of problem-solving displayed by students. The entire show of student work will be read, and the results will be used to measure and decide whether or not the indicators of higher-order thinking skills have been met (ie: the emergence of students' ability to present solutions in several different problem-solving procedures).

Essay tests are also used to see students' mathematical communication skills. Assessment of mathematical communication skills using holistic assessment rubrics. This assessment can be used to see the achievement of indicators of students' mathematical communication skills (ie: Students should demonstrate clarity in delivering job outcomes so that others can understand them).

\section{Data Analysis Techniques}

Data were analyzed using a multivariate F-test. Multivariate F-test was used in tests of balance (to see if the two groups had the same academic achievement) and the hypothesis test (to see is there a difference in high-level thinking skills and mathematical communication between the two groups). The results of the multivariate F-test only showed whether there were differences in the effect of the treatment given to each variable (HOTs and mathematical communication skills). Therefore, to see further which treatment is better for each variable a univariate test is performed using an independent t-test.

The Independent t-test was used to find out: 1) whether the high-level thinking skills of mathematics in students subjected to learning with the PINTER learning model were better than the higher-level thinking skills of mathematics in students who were subjected to traditional learning models, and 2) whether mathematical communication skills in students subjected to the PINTER learning model is better than mathematics communication skills in students who are subjected to traditional learning models. 


\section{Hypothesis}

The hypotheses of this study are: 1) Mathematical higher-order thinking skills in students subjected to learning with the PINTER model are better than mathematical higher-order thinking skills in students subjected to learning with traditional learning models, and 2) Mathematical communication skills in students subjected to learning with the PINTER mathematics learning model is better than mathematics communication skills in students who are subjected to learning with traditional learning models

\section{FINDINGS}

Data collection was carried out in two groups, groups that were subjected to the PINTER learning model and groups that were subjected to traditional learning models. Both groups are in a balanced condition both in terms of academic ability, teacher quality, and the textbook used. Both groups were taught by teachers of the same quality, indicated by each teacher having a certificate of education as a professional teacher. Both groups alike use electronic books published by the Ministry of National Education. The only distinction between the two classes is how the learning paradigm is treated with. The academic ability of both groups is guaranteed by using the Multivariate F-test. The results of the balance test are shown in Table 3 .

Table 3

Summary of the balance test in the two groups on academic ability

\begin{tabular}{lcccccc}
\hline Group & $\mathrm{N}$ & $\mathrm{S}$ & $\overline{\bar{X}}_{1}-\overline{\bar{X}}_{2}$ & $\mathrm{~T}$ & $\mathrm{~F}$ & $\mathrm{~F}_{\mathrm{tab}}$ \\
\hline Experiment Group & 91 & {$\left[\begin{array}{cc}115,467 & 74,181 \\
74,181 & 105,703\end{array}\right]$} & {$\left[\begin{array}{c}1,926 \\
2_{x}, 976\end{array}\right]$} & 3,933 & 1,956 & 3,045 \\
\hline Control Group & 96 & & & \\
\hline
\end{tabular}

Based on the calculation results following the above summary, it shows that $F_{\text {obs }}=1.956$ $<3.045=F_{\text {tab }}$, so the decision H0 is taken. Thus, it can be concluded that there is no difference between the initial ability of students subjected PINTER mathematics learning model and students who are subject to the traditional learning model (the ability initially equal). Treatment was given to both groups for 5 meetings. At the end of the meeting, a test is given with the results shown in Table 4.

Table 4

Description of result test of HOTs and mathematics communication test

\begin{tabular}{llllllllllll}
\hline \multirow{2}{*}{ Group } & \multicolumn{1}{l}{ HOTs } & \multirow{2}{*}{ N } & $\bar{X}$ & Sd & Max & Min & $\mathrm{n}$ & $\bar{X}$ & Sd & Max & Min \\
& & & & & & & & & \\
\hline Exp Group & 91 & 59,868 & 15,143 & 93 & 27 & 91 & 70,242 & 15,975 & 95 & 25 \\
\hline Ctrl Group & 96 & 43,240 & 16,037 & 80 & 7 & 96 & 51,198 & 18,435 & 90 & 15 \\
\hline
\end{tabular}

Based on these results, a multivariate F-test is then performed to determine the difference in the effect of the application of the two learning models on high-level thinking skills and students' mathematical communication on algebraic material. F-test results obtained $F_{\text {obs }}=34.285>3.045=F_{\text {tab }}$, so the decision $\mathrm{H}_{0}$ was rejected. Thus, it 
can be concluded that there is a difference in influence between the PINTER mathematics learning model and the traditional learning model on high-level thinking skills and mathematics communication of junior high school students on algebra material.

Based on the statistical test decision above, then a univariate test is performed to determine the difference in the effect of learning on each variable. Table 5 contains a list of the test findings.

Table 5

A summary t-test on variables of higher-order thinking skills

\begin{tabular}{llllllll}
\hline Group & $N$ & $\bar{X}$ & $s d$ & $S p$ & $t_{\text {obs }}$ & $t_{\text {tab }}$ & Desicion \\
\cline { 1 - 6 } Experimen Group & 91 & 59,868 & 15,143 & \multirow{2}{*}{15,609} & \multirow{2}{*}{7,828} & \multirow{2}{*}{1,649} & $\begin{array}{l}\mathrm{H}_{0} \\
\text { rejected }\end{array}$ \\
\hline Control Group & 96 & 43,240 & 16,037 & &
\end{tabular}

Based on the Table 5, it shows that $t_{\mathrm{obs}}=7.828>1.649=t_{\text {tab }}$ so $\mathrm{H}_{0}$ decision is rejected. Thus it can be concluded that higher-order thinking skills in students who are subjected to the PINTER mathematics learning model are better than higher-order thinking skills in students who are subjected to traditional learning models.

Table 6

Summary of t-tests on mathematical communication skill variables

\begin{tabular}{llllllll}
\hline Group & $N$ & $\bar{X}$ & $s d$ & $s p$ & $t_{\text {obs }}$ & $t_{\text {tab }}$ & Desicion \\
\cline { 1 - 3 } Experimen Group & 91 & 70,242 & 15,975 & \multirow{2}{*}{17,282} & 7,532 & \multirow{2}{*}{1,649} & $\begin{array}{l}\mathrm{H}_{0} \\
\text { rejected }\end{array}$ \\
\hline Control Group & 96 & 51,198 & 18,435 & & & &
\end{tabular}

Based on the Table 6, it shows that $\mathrm{t}_{\mathrm{obs}}=7,532>1,649=\mathrm{t}_{\text {tab }}$ so $\mathrm{H}_{0}$ decision is rejected. Thus it can be concluded that mathematics communication skills in students who are subjected to the PINTER mathematics learning model are better than mathematics communication skills in students who are subjected to traditional learning models.

This study concludes that: 1) students' higher-order thinking skills that are subjected to PINTER mathematics learning are better than students' higher-order thinking skills that are subjected to traditional learning models, and 2) students' mathematical communication skills that are subjected to learning PINTER mathematics are better than communication skills student mathematics that is subject to traditional learning models.

The above results are also shown by the work of students who have achieved indicators of higher-order thinking skills and mathematical communication the emergence of students' ability to propose solutions in many different problem-solving processes is an indication of achieving students' high-level reasoning skills, while the achievement of students' mathematical communication metrics is demonstrated by the consistency with which work results are delivered so that they can be interpreted and understood by others. In problem-solving, some of the outcomes of student work can be seen as follows. 
Problem: There would be $2 / 3$ as many girls in the class if 8 boys went to the restroom. If eight girls go to the bathroom, there will be twice as many boys as girls. In this class, how many boys and girls are there?

Some of the results of student work are displayed in Figure 1.

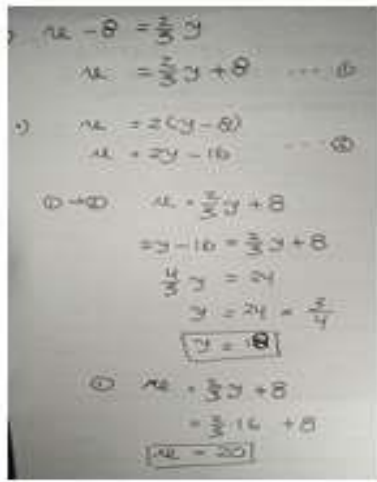

Solution 1

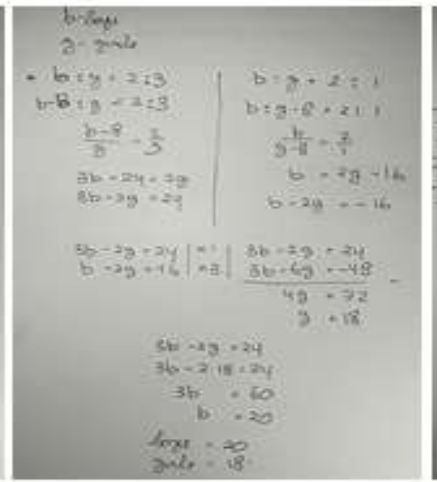

Solution 1

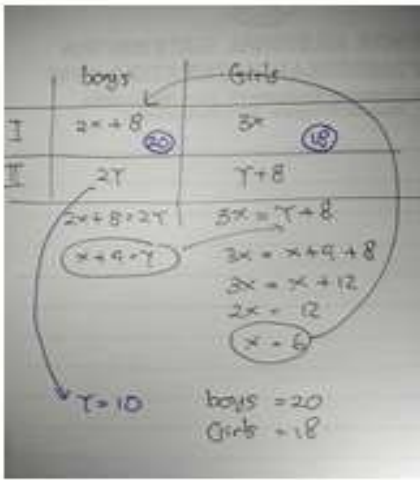

Solution 3

Figure 1

Sample solution of giver problem

In solution 1 , the completion procedure used is to separate boys with the variable " $x "$ and girls with the variable " $y "$. By adjusting the facts presented in the problem, 2 equations are arranged, namely $x=(2 / 3) y+8$ and $x=2 y-16$. By using the elimination and substitution method, $x=20$ and $y=18$ are obtained.

In solution 2 , the completion procedure uses a comparison between boys " $b$ " and girls " $g$ " following the facts in the problem. From the two conditions, two equations $3 b-2 g$ $=24$ and $b-2 g=-16$. are compiled. Both equations are then solved using the elimination and substitution method. Obtained $b=20$ and $g=18$.

In solution 3 , the completion procedure uses a table. Each row in the table presents conditions that correspond to the facts of the problem. Each condition is arranged in the form of algebraic equations. By algebraic manipulation, the result $x=6$. This result is not yet finished, then substitution $\mathrm{x}$ is done in condition 1 to count boys and girls. It was found that there were 20 male students and 18 female students.

These three solutions, although both use algebraic manipulation with the method of elimination and substitution, procedurally, it can be said that each solution has a different completion procedure. The difference in this procedure is certainly a result of the learning experience gained during learning with the PINTER model.

\section{DISCUSSION}

The results of the study have shown that the implementation of the PINTER learning model it produces higher-order mathematical thinking skills better than the application of traditional learning models. This can occur because the PINTER learning model encourages students to be active in learning activities. Expository learning is popular in 
Indonesian traditional education. The instructor is in charge of learning tasks in traditional learning. To construct positive learning environments, students become passive and not actively active. As a result, learning has become more mechanistic, with students memorizing information and imitating the teacher's completion procedures. This contradicts the fact that higher-order thinking skills are activities that think not merely to remember facts or retell what was received to others (Thomas \& Thorne, 2009). To obtain knowledge that is not merely just remembering, it is necessary to make linkages between material so that it becomes a unified cognitive structure. Higher-order thinking skills occur when someone obtains new information, understands it, and relates it to other knowledge, and applies it to the context of other new problems (Hasan, Rosli, \& Zakaria, 2016). The activity of linking a lot of this information to the PINTER learning model occurs in stage 1 , presentation to real life, one of which is activating prior knowledge. Students are immediately exposed to the definitions of variables, coefficients, and constants in algebraic material without the use of any teaching aids other than writing or notes on the surface. Students seem to be expected to memorize the idea of algebra.

The emergence of high-level mathematical thinking skills is characterized by the existence of non-algorithmic steps, unpredictable answers, produce many solutions, the existence of uncertain solutions, involving the independence of thinking, and the existence of hard efforts to obtain answers (Resnick, 1992). These characteristics in the PINTER mathematics learning model can be fulfilled at the Investigation step. In this step, students are encouraged to do spontaneous exploration by using all possible strategies that students can solve problems. Next, students make generalizations about the problems and solutions that have been presented. This does not occur in traditional learning because most students only follow the completion steps exemplified by the teacher. To support the various characteristics of the HOTs, the PINTER mathematical model presents problems in the form of an open-ended student worksheet. Open-ended student worksheets are prepared by meeting the following question criteria: they are non-routine, complex problems, they are possible to solve in many ways, the solution is unpredictable, requires completion of hard work (Retnawati, et al, 2017). The characteristics of such questions do not emerge in traditional learning because the questions in the learning are mostly routine questions that only encourage mechanistic abilities whose completion steps have been guessed.

These results guide the implementation of learning by emphasizing the linkage of material concepts. The linkage between the concepts of this material will be very useful to be reproduced in solving non-routine problems. Thus, the teacher should always repeat the teaching material that has been delivered and related to the material taught at that time. Giving non-routine problems and giving opportunities to students to carry out investigative activities is also very necessary to build the potential of students' mathematical thinking skills. When students experience obstacles, the teacher can assist by giving instructions to present solutions with various possible solutions if needed. Presentation of various solutions to this solution will open students' insight into thinking that a problem can not only be solved in one way but can be solved by various procedures. This will encourage students to be more creative in thinking. 
Students will be encouraged to use all of their thinking skills and to explain their suggestions as a result of the investigation activity, which will improve their understanding. Individual elaboration activities still need to be carried out to be able to apply all the information regarding the application of various concepts and settlement procedures that can be utilized by each student individually in solving new problems. At the end of the lesson, the teacher reinforces the form of giving feedback, conducting reflection activities, and reviewing the learning activities that have been carried out. This will make all the information stored in students' long-term memory at any time can be called upon to solve the problem in another form.

The difference in learning activities is what makes the differences in the results of higher-order thinking skills and mathematical communication in the two groups. However, the average value of high-order thinking skills in the experimental group showed 59.868. This average value is not large enough, but it is understandable considering that learning with the PINTER model is still counted as something new. On the other hand, giving open-ended problems is also still not commonly used before the implementation of the PINTER model. As a result, students still need to use more mathematical thinking skills so they are accustomed to solving problems with various procedures.

The results also showed that students' mathematical communication skills that were employed by the PINTER mathematics learning model were better than learning with traditional models. Learning with the PINTER mathematical model encourages students to communicate well at the step of team activities and explanation and reasoning. Discussions that occur in small groups and class discussions help students freely convey ideas, reasons, opinions, rebuttals, and test their knowledge. This has a positive impact on building students' new cognitive structures. The cognitive structure is built and strengthened by testing the ideas that exist in itself to be compared with other people's ideas. Students can also give reasons and objections to ideas that conflict with their ideas. This results in improved knowledge of knowledge. This does not happen in traditional learning where students are more passive, students are reluctant to think, even afraid if viewed differently from other student work. Thus students will get nothing but follow what the teacher or his friend has done.

The mathematical communication skills of students in the two groups are very contrasting. In traditional learning, students tend to be passive, do not talk much, and are reluctant to discuss both with the teacher and other students. This looks very different from the PINTER model. Students are very enthusiastic about their learning activities so that the discussion goes very well. This is not surprising if the results obtained in the two groups differ greatly (mean score 70, 242 compared to 51,198).

The results of this study provide clues to the importance of managing to learn to optimize the potential for higher-level thinking and mathematical communication of students. The results of these studies can be one alternative learning that can be implemented by teachers and other researchers. Equally important is the need for habits and consistency in managing learning. This habituation will also be the key to success in achieving further learning. 


\section{CONCLUSION}

Based on the results of the study and concluded that: 1) students' high-level thinking skills that are subjected to learning PINTER mathematics are better than students' highorder thinking skills that are subjected to traditional learning models, and 2) students' mathematical communication skills that are subjected to learning PINTER mathematics are better than students' mathematical communication skills that are subjected to traditional learning models.

The findings of this study encourage teachers to use the PINTER mathematics learning model in their classrooms, especially when teaching algebra. However, it does not rule out the possibility of PINTER mathematics learning models can be applied to other material. The teacher can modify the syntax of learning according to needs and must pay attention to the presentation of non-routine problems as one of the keys to pushing students' thinking skills towards a higher level.

\section{ACKNOWLEDGEMENT}

This study was part of a doctoral dissertation at Sebelas Maret University Surakarta's Faculty of Teacher Training and Education. Thank you to everyone who has helped support this research, particularly the sponsors, teachers, and students who were directly involved. The author truly hopes that everyone will benefit from this discovery to increase education quality.

\section{REFERENCE}

Absolem, Y. (2016). Assessment techniques and students' higher-order thinking skills. International Journal of Secondary Education, 4, 1-12.

Anderson, L. W., and Krathwohl, D. R. (2001). A taxonomy for learning, teaching, and assessing: A revision of Bloom's taxonomy of educational objectives. New York: Longman Community Level

Bagley, T, and Gallenberg, C. (1992). Assessing Students' dispositions: Using Journal to Improve Students' Performance. Mathematics Teacher, 85, 660-663.

Center for Development and Learning (2013) URL: http://www.cdl.org/index.html.

Chapin, S. H., O'Connor, C., \& Anderson, N. C. (2003). Classroom Discussions: Using Math Talk to Help Students Learn, Grades K-6. Sausalito, CA: Math Solutions.

Cooke B. D., \& Bucholz D. (2005, June). Mathematical communication in the classroom. Early Childhood Education Journal, 32(6), pp. 365-369.

Cramer, K., \& Karnowski, L. (1995). The importance of informal language in representing mathematical ideas. Teaching Children Mathematics, 1(6), pp. 332-336.

Goethal, P.L. (2013). The Pursuit of Higher-Order Thinking in the Mathematics Classroom: A Review. Center for Faculty Excellence, United States Military Academy, West Point: NY. Tersedia di http://www.usma.edu/cfe/literature/goethals_13.pdf

Guest, K. B. (2011). Effects of Computer-Based Intervention on Higher Order Thinking Skills and Implications for Response to Intervention (RTI). Dissertation: Walden University 
Heng, C.S., dan Ziguang, Y. (2015). Framework of Assessment for the Evaluation of Thinking Skills of Tertiary Level Students. Advances in Language and Literary Studies, 6(5), 67-72.

Heong, et. al. (2011). The Level of Marzano Higher Order Thinking Skills among Technical education Students. International Journal of Social Science and Humanity, 1(2), 121-125.

Hill, C (2010). When traditional won't do: experiences from a "lower-level" mathematics classroom. The Clearing House, 83, 239-243. DOI: $0.1080 / 00098655.2010 .484439$ http://www.cala.fsu.edu/files/higher_order_thinking_skills.pdf.

In'am, A., \& Sutrisno, E. S. (2021). Strengthening Students' Self-efficacy and Motivation in Learning Mathematics through the Cooperative Learning Model. International Journal of Instruction, 14(1), 395-410. https://doi.org/10.29333/iji.2021.14123a

Intrator, D. (2016). Communication Skills Are Key To 21st Century Success. Available at pada https://thecreativeorganization.com/ communication-skills-and-success/

Katz, V. (2007). Stages in the history of algebra with implications for teaching. Educational Studies in Mathematics, 66, 185-201.

Kaya, D. Aydin, H. (2014). Elementary Mathematics Teachers' Perceptions and Lived Experiences in Mathematical Communication. Eurasia Journal of Mathematics, Science \& Technology Education, 12(6), 1619-1629. DOI: 10.12973/eurasia.2014.1203a

King, F.J., Goodson, L., and Rohani, F. (1998). Higher-Order Thinking Skills: Definitions, Strategies, and Assessment. http://www.cala.fsu.edu/files/higher_order_thinking_skills.pdf.

Kruger, K. (2013). Higher-Order Thinking. Hidden Sparks, Inc. New York, New York.

Limbach, B. \& Waugh, W. (2006). Developing Higher Level Thinking. In Journal of Instructional Pedagogies, 1-9.

Lomibao, LS. Luna, CA, dan Namoco RA. (2016). The Influence of Mathematics Communication on Students' Mathematics Performance and Anxiety. American Journal of Educational Research, 4(5), 378-382.

Lopez, J., and Whittington, M. (2001) Higher-Order Thinking in a College Course: A Case Study. Proceedings of the Annual NACTA Conference, Lincoln, Nebraska, pp. 22 29.

Meel, D. (1999). Email dialogue journals in a college calculus classroom: A look at the implementation and benefits. Journal of Computers in Mathematics and Science Teaching. 18(4), 387-413.

National Council of Teachers of Mathematics. (2000). Principles and Standards for School Mathematics. NCTM, Reston, Virginia. 
National Mathematics Advisory Panel. (2008). Foundations for success: The final report of the national mathematics advisory panel. U.S. Department of Education: Washington, DC.

Naveneedhan C G. (2007). What is meant by cognitive structures? How does it influence teaching-learning psychology? IRA-International Journal of Education \& Multidisciplinary Studies, 07(02), 89-98.

Pecka, S. L. (2014). Evaluating Higher Order Thinking In Online Discussions. Dissertation: The Graduate College in the University of Nebraska Medical Center

Protheroe, N. (2007) What Does Good Math Instruction Look Like? Principal, 7(1), 51-54.

Resnick, L. (1987). Education and Learning to Think. National Academy Press: Washington DC.

Sahin, O, and Soylu, Y. (2011). Mistakes and misconceptions of elementary school students about the concept of 'variable. Procedia Social and Behavioral Sciences. 15, 3322-3327.

Saido, GAM. Siraj, S. Nordin, AB. (2015). Teaching Strategies For Promoting Higher Order Thinking Skills: A Case Of Secondary Science Teachers. Malaysian Online Journal Of Educational Management (MOJEM), 3(4), 16 - 30.

Sari, Y. I., Sumarmi., Utomo, D. H., \& Astina, I K. (2021). The Effect of Problem Based Learning on Problem Solving and Scientific Writing Skills. International Journal of Instruction, 14(2), 11-26. https://doi.org/10.29333/iji.2021.1422a

Stein, M., Smith, M., Henningsen, M., \& Silver, E. (2000). Implementing standardsbased mathematics instruction: A casebook for professional development. New York: Teacher College.

Sutrisno, D., \& Retnawati, H. (2018). Korelasi Kemampuan Berpikir Tingkat Tinggi dan Prestasi Belajar Siswa MAN 3 Yogyakarta. Edumatica, 8, 17-22.

Tajudin, N. M. (2017). Role of higher order thinking skills in enhancing mathematical problem solving. Man In India, 97(17), 209-214.

Thomas, A., and Thorne, G. (2010) How to Increase Higher-Order Thinking. Center for Development and Learning, Metairie, Louisiana.

Thompson, T. (2008) Mathematics Teachers' Interpretation of Higher-Order Thinking in Bloom's Taxonomy. International Electronic Journal of Mathematics Education, 3(2), pp. 96-109.

Yuniarti, I. P. \& Fitri, N. (2019).the impact of higher order thinking skills (hots) instructions in teaching efl speaking skill from the perspective of students'motivation. Lingua Cultura, 13(4), pp. 313-319. DOI: 10.21512/lc.v13i4.6105

Zoller, U., \& Tsaparlis, G. (1997). Higher and lower-order cognitive skills: The case of chemistry. Research in Science Education, 27(1), 117-130 